\title{
ETNOBOTANI JERNANG MASYARAKAT PEDALAMAN BIREUN
}

\section{Ethnobotany Jernang of People in Rural Bireun}

\author{
Muhammad Ridhwan', Nurlena Andalia' ${ }^{1}$, Armi ${ }^{1}$, dan \\ Yuhasriati ${ }^{2}$ \\ ${ }^{1}$ Universitas Serambi Mekkah, Banda Aceh, Aceh, Indonesia \\ ${ }^{2}$ Universitas Syiah Kuala, Banda Aceh, Aceh, Indonesia \\ Coresponding author: ridhwan4000@gmail.com
}

\begin{abstract}
Jernang is one of the wild trees that are from the family of rattan with the genus of Daemonorops. The objective of this research is to know the availability, user, harvest, and conservation of the Jernang as well as the barrier faced by the jernang hunters, jernang harvest, and jernang conservation. This study is the done using descriptive research methodology. Respondents were chosen by purposive sampling. They were chosen with special considerations such as they must be the jernang hunters or the people who well understand the jernang. The data were collected through interview and participant observation and then analyzed descriptively. The research findings showed that the respondents still hunted the jernang in the forest and they sold to the buyers in their villages. Jernang fruits were processed by extracting them to get their substances. The conservation efforts have many threats due to the expansion of the palm plantation. The lack of people knowledge of good jernang for the seed is also one of the barriers of conservation.
\end{abstract}

Keywords: ethnobotany, jernang, rural community in Bireun Regency

\section{PENDAHULUAN}

Jernang merupakan salah satu jenis hasil hutan yang diperoleh dari sejenis rotan dari marga Daemonorops (Matangaran et al., 2012). Marga Daemonorops mempunyai sekitar 115 spesies (Rustiami et al., 2004). Buah Rotan Daemonorops dapat menghasilkan suatu resin berwarna merah yang disebut jernang 
(Waluyo, 2008), dalam dunia perdagangan sering disebut dengan dragon's blood (Pearson, 2002). Resin diperoleh dari buah jernang betina (Asra et al., 2012), atau dari jernang hermaprodit. Resin jernang (dragon's blood) diperoleh dari Daemonorops draco Blume, Daemonorops didymophilla Becc, Daemonorops brathystachys Furtado, Daemonorops draconcellus Becc, Daemonorops mattanensis Becc, Daemonorops propincua Becc, dan Daemonorops micracantha (Grift) Matt (Januminro, 2000). Resin Dragons blood juga diperoleh dari sel, jaringan, dan organ lain dari Jernang Daemonorops draco Blume (Gupta et al., 2008).

Jernang digunakan dalam industri seperti bahan baku pewarna dalam industri keramik, marmer, alat-alat batu, kayu, kertas, dalam dalam industri farmasi (Purwanto et al., 2005). Hasil ekstraksi getah jernang dapat digunakan sebagai anti bakteri, anti fungal, dan penyembuh luka (Waluyo et al., 2015), anti peradangan, obat lambung, anti tumor, antioksidan, bahkan di beberapa tempat dipakai dalam praktek perdukunan (Gupta et al., 2008). Karena banyak keperluan dalam industry maka getah jernang berharga sangat tinggi dalam perdagangan. Di tingkat petani saja harga getah (resin) jernang bisa mencapai 5 juta rupiah perkilogramnya. Petani biasanya menjual buah segar dengan harga 400 ribu rupiah perkilogramnya.

Harga yang sangat tinggi membuat petani sangat tergesa gesa dalam memanen buah jernang. Potensi produksi Getah Jernang semakin menurun bahkan cendrung semakin langka karena pola produksi yang tidak lestari dan adanya pengembangan tanaman perkebunan yang sangat ekspansif. Selain itu populasi Rotan Jernang dari tahun ke tahun semakin berkurang, karena tidak berlangsungnya sistem regenerasi alami secara optimal dan pola panen produksi buah dilakukan dengan cara menebang pohonnya (Sulasmi et al., 2012).

Desa Blang Mane Kecamatan Peusangan Selatan merupakan salah salah satu desa yang ada di Kabupaten Bireun yang berbatasan langsung dengan hutan belantara di Kabupaten Bener Meriah. Selama ini Desa Blang Mane merupakan salah satu desa yang penghasil getah jernang yang sangat penting. Namun 
demikian beberapa tahun belakangan ini produksi buah jernang dari hutan cenderung menurun. Hal ini disebabkan pembukaan lahan penanaman sawit yang sangat massif oleh Perusahaan Perkebunan. Hal ini menyebabkan keberlanjutan tanaman jernang di hutan semakin berkurang. Namun demikian dari hasil observasi belum banyak masyarakat yang menanan jernang di kebunnya. Untuk itu perlu dilakukan penelitian bagaimana pandangan masyarakat terhadap keberlangsungan hidup jernang di daerah mereka. Tujuan dari penelitian ini adalah untuk mengetahui keberadaan jernang, penggunaan jernang, hambatan yang dialami pencari jernang, pemanenan jernang, dan pelestarian jernang.

\section{METODE PENELITIAN}

Penelitian ini dilaksanakan pada bulan Mei sampai Juli 2018 di Desa Blang Mane Kecamatan Peusangan Selatan Kabupaten Bireun. Penelitian ini merupakan penelitian deskriptif. Responden dipilih secara Purposive sampling. Responden dipilih dengan pertimbangan tertentu, yaitu responden yang terlibat dalam pencarian jernang atau yang mengerti tentang jernang. Data diperoleh dengan interview dan observasi partisipatif.

Data dianalisis secara deskriptif. Data yang dianalisis berupa informasi tentang keberadaan jernang, penggunaan jernang, hambatan yang dialami pencari jernang, pemanenan jernang, dan pelestarian jernang.

\section{HASIL PENELITIAN DAN PEMBAHASAN}

\section{Kondisi Daerah Penelitian}

Desa Blang Mane Kecamatan Peusangan Selatan merupakan salah satu desa dalam Kabupaten Bireun. Luas Desa Blang Mane menempati rangking pertama di Kecamatan Peusangan Selatan yaitu seluas 2541 hektar dengan jumlah penduduk 748 jiwa (BPS, 2018). Desa Blang Mane merupakan desa pinggiran yang berbatasan langsung di sebelah selatannya dengan Kabupaten Bener Meriah. Sedangkan sebelah utara berbatasan dengan Desa 
Tanjong Beuridi, sebelah timur berbatasan dengan desa Pulau Harapan, dan Sebelah Barat berbatasan dengan Kecamatan Juli.

Iklim di Desa Blang Mane adalah iklim Tropis. Suhu Rata rata tahunan adalah $27,2^{\circ}$ Celcius. Curah hujan rata-rata adalah $1558 \mathrm{~mm}$ (Anonimous, 2018). Curah hujan tersebut sangat cocok untuk pertumbuhan jernang. Curah hujan yang diperlukan oleh tanaman jernang adalah $1.000-1.500 \mathrm{~mm}$ per tahun. Curah hujan di atas $2000 \mathrm{~mm}$ pertahun akan menghambat pembungaan (Sahwalita, 2014).

\section{Pembungaan Jernang}

Hasil penelitian didapatkan bahwa menurut responden buah jernang diperoleh dari tumbuhan jernang betina. Sedangkan jernang jantan tidak didapatkan buah. Jernang jantan diperlukan untuk menyerbuki bunga betina. Gambar 1A menunjukkan jernang di daerah penelitian sedang berbunga. Populasi yang didapatkan dari daerah sekitar penelitian ini hanya ada 5 perdu dan semuanya berjenis kelamin betina. Tidak ada satu perdu pun didapatkan jernang jantan. Gambar 1B memperlihatkan jernang betina tanpa pembuahan menghasilkan buah. Hal ini diperkirakan diakibatkan terjadinya apomiksis, yaitu berkembangnya buah dari tumbuhan betina tanpa terjadinya penyerbukan. Apomiksis yang terjadi adalah apomiksis fakultatif, artinya pembuahan dapat terjadi dengan atau tanpa penyerbukan dari serbuk sari tumbuhan jernang jantan (Asra, et al., 2016).
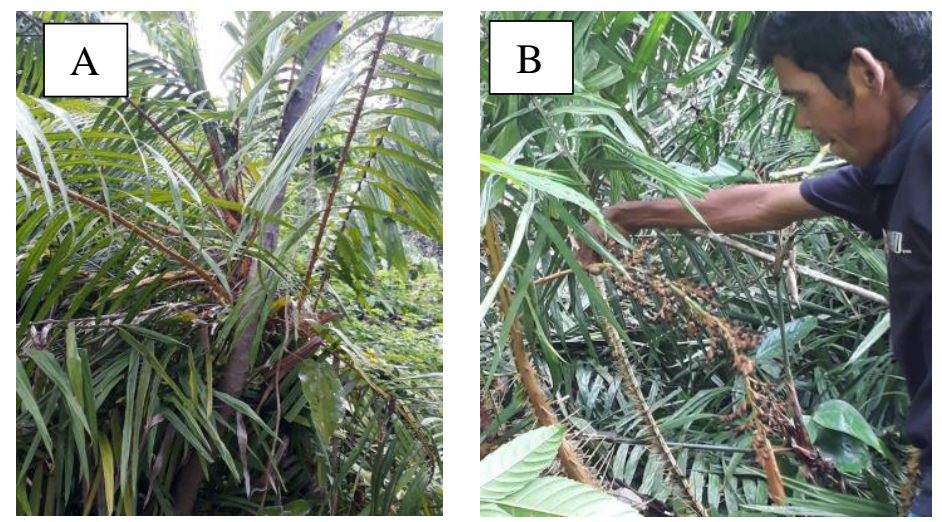

Gambar 1. A) Jernang sedang berbunga, B) Jernang sedang berbuah 


\section{Pemetikan Buah Jernang}

Buah jernang yang dipetik masyarakat Blang Mane selama ini adalah jernang liar yang ada di hutan. Pencari buah jernang masuk ke dalam hutan dan mencari buah jernang yang bisa dipetik. Buah jernang dengan mutu super ditandai dengan tampak jernang keluar dari bawah kulitnya atau buahnya setengah tua, berbentuk bulat telur agak lonjong (Matangaran, 2012). Umur buah jernang mutu super diperkirakan 8 bulan setelah bunga merekah, setelah itu kualitas resin jernang nya sudah menurun. Menurut responden buah jernang di habit aslinya bisa berumur 2 tahun kalau tanpa dipetik.

Buah jernang biasanya diambil dengan cara memotong dengan kait yang diikat pada ujung galah. Buah juga dipetik dengan cara memanjat batang kayu tempat sandaran rotan jernang. Terkadang masyarakat juga mengambil buah jernang yang sudah sangat tinggi dengan cara menarik batangnya sehingga batang melorot ke bawah. Batangnya yang berduri mereka bersihkan dulu dengan parang sehingga memudahkan menariknya. Menurut mereka batang jernang yang ditarik tersebut tidak akan merusak jernang karena nantinya jernang tersebut akan memanjat ke atas pohon inang lagi.

Pada umumnya panen raya dilakukan pada bulan April dan September (Winarni et al., 2005). Namun menurut masyarakat, jernang berbunga secara bertingkat tingkat seperti kelapa atau pinang. Artinya jernang berbunga dan berbuah sepanjang tahun (Matangaran et al., 2012). Harga yang mahal membuat masyarakat memetik buah jernang dengan kualitas apa saja. Buah yang baru mekar dari bungapun ikut dipetik walaupun harganya murah. Menurut responden harga buah jernang pada bulan Agustus 2018, untuk buah super dibeli oleh pengumpul seharga 400 ribu rupiah perkilogramnya. Buah yang baru mekar dari bunga dibeli seharga 70 ribu sampai 100 ribu rupiah.

\section{Penggunaan Jernang}

Jernang oleh masyarakat Desa Blang Mane Kecamatan Peusangan Selatan digunakan terutama untuk menambah ekonomi keluarga. Di samping itu jernang juga digunakan untuk obat- 
obatan, misalnya obat lambung, dan obat luka. Dalam menambah ekonomi keluarga, masyarakat yang mencari buah jernang di hutan langsung dijual kepada toke yang yang ada di desa. Harga yang dijual bervariasi, mulai dari harga 100 ribu perkilogramnya sampai 400 ribu perkilogram buahnya. Toke kemudian mengolah buah jernang menjadi resin jernang.

Resin jernang diperoleh dari kulit buah jernang dengan dengan cara ekstraksi. Cara ekstraksi yang dilakukan toke di desa Blang mane adalah ekstraksi Basah. Menurut Gafar (2010), ekstraksi basah lebih bagus dibandingkan dengan ekstraksi kering. Karena dengan ekstraksi basah kandungan kotorannya lebih kecil dibandingkan ekstraksi kering. Ekstraksi dilakukan dalam beberapa langkah. Pertama buah dikering anginkan beberapa hari, kemudian ditumbuk secara tradisional dengan Jingki (alat penumbuk tradisional) (Gambar 2A). Hasil dari tumbukan menjadi dedak dan kemudian direndam di dalam air selama 1 jam untuk memisahkan endapan resin dan kotoran (Gambar 2B).
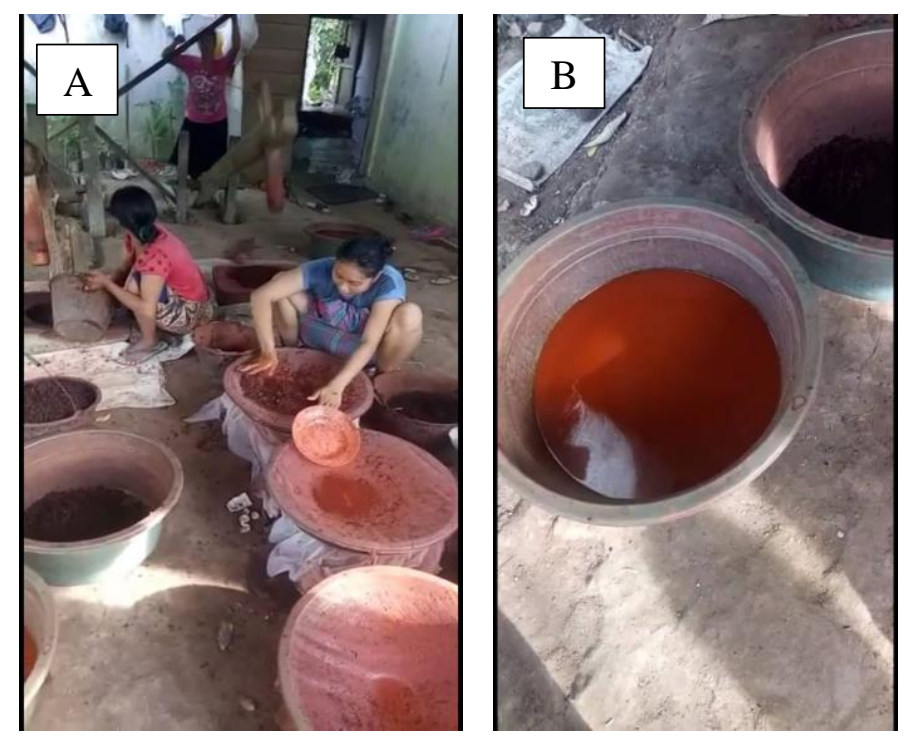

Gambar 2. A) Buah Jernang ditumbuh dengan Jingki dan proses ekstraksi basah, B) Hasil Ekstraksi yang sudah bersih dari kotoran

Warna tepung resin jernang yang diperoleh berwarna merah. Resin yang diperoleh dari buah jernang berwarna merah, 
termasuk ke dalam resin keras berupa padatan yang mengkilap, bening, atau kusam, dan berbau menyengat, dan meleleh bila dipanaskan (Waluyo, 2013 ; Coppen, 1995).

Masyarakat Desa Blang Mane juga menggunakan jernang untuk obat obatan. Biasanya mereka menggunakan untuk obat lambung dan obat luka. Jernang juga dapat dimanfaatkan untuk obat luka, obat sakit gigi, dan digunakan sebagai obat setelah melahirkan (Yetty et al., 2013). Ada sekitar 36 senyawa kimia penting terdapat dalam resin jernang yang berpotensi sebagai bahan bioaktif, diantaranya dracorhodin, nordracorhodin, nordracorubin, dracorubin, dracoflavan A, Abietic Acid (Gupta et al., 2008). Senyawa kimia dracorhodin (2H-1-benzopyran-7-on) merupakan penciri dari resin jernang dragon's blood (Waluyo, 2013). Unsur kimia dracorhodin dan dracorubin berpotensi untuk anti microba Staphylococcus aurius, Klebsiella pneumoniae, Mycobacterium smegmafis, dan Candida albicans (Rao et al., 1982). Ekstrak jernang dengan pelarut n-heksana pada jernang Daemonorops draco dan Daemonorops melanocahetes bersifat antimicroba pada bakteri Bacillus subtilis dan jamur Candida albicans. Sedangkan ekstrak jernang dengan pelarut etil asetat bersifat sebagai obat penyembuh luka (Waluyo dan Pasaribu, 2015). Senyawa kimia dalam jernang (Dragons blood) juga berpotensi sebagai anti virus, anti tumor, meningkatkan aktivitas sitotoksis (Xia et al., 2006), dan mengaktifkan enzim antioksidant (Ran et al., 2014).

\section{Pelestarian Jernang}

Hasil penelitian menunjukkan bahwa masyarakat desa Blang Mane selama ini belum membudidayakan tanaman jernang di kebunnya. Alasan masyarakat tidak membudidayakan jernang dikebunnya karena takut dicuri. Kekhawatiran terhadap pencurian itulah makanya selama ini mereka mengandalkan mencari jernang di hutan.

Namun dalam 5 tahun terakhir hutan tempat mereka mencari jernang semakin berkurang karena adanya alih guna lahan untuk perkebunan kelapa sawit (Gambar 3) sehingga semakin lama keberadaan jernang semakin langka (Lestari, 2017). Diperkirakan 
dua tahun ke depan tidak ada lagi jernang alam di desa tersebut. Hambatan lain dalam budi daya jernang adalah tingginya keanekaragaman genetic jernang liar yang ada di hutan (Asra, et al., 2018), sehingga mereka khawatir jernang mereka tanam nantinya tidak berbuah. Di samping itu mereka juga khawatir jernang yang mereka tanam berjelis kelamin jantan, sehingga tidak berbuah. Mereka belum bisa membedakan jenis kelamin batang jernang pada saat penanaman. Mereka menemukan banyak dihutan itu jernang yang tidak berbuah tapi hanya berbunga saja. Rasio seks jernang secara alami adalah 1:1 yaitu jumlah antara jantan dan betina sama banyak di hutan alami. Namun demikian bisa juga terjadi penyimpangan rasio seks jernang jernang jantan dan betina yang dibudidayakan yaitu 1:1,2 (Asra et al., 2012).

\section{KESIMPULAN}

Hasil penelitian menunjukkan bahwa responden masih mencari buah jernang di hutan. Namun upaya pelestarian masih minim dilakukan masyarakat yang disebabkan oleh degradasi lahan menjadi kebun sawit. Selain itu pengetahuan masyarakat mengenai jenis jernang yang baik untuk bibit dan pencurian buah jernang juga menjadi hambatan dalam pelestarian.

\section{DAFTAR PUSTAKA}

Anonimous. (2018). Iklim Bireun. https://en.climatedata.org/asia/indonesia /aceh/bireuen-993645/

Asra, R., Syamsuardi, M., \& Witono, J. (2018). Genetic Diversity in Daemonorops draco (Willd.) Blume (Arecaceae) Among Wild and Cultivate Populations inferred by RAPD Markers. SABRAO J. Breed. Genet, 50(2), 145-155.

Asra, R., Syamsuardi, S., Mansyurdin, M., \& Witono, J. R. (2012). Rasio Seks Jernang (Daemonorops Draco (Willd.) blume) Pada Populasi Alami Dan Budidaya: Implikasi Untuk Produksi Biji. Buletin Kebun Raya, 15(1), 1-9. 
Asra, R., Syamsuardi, S., Mansyurdin, M., \& Witono, J. R. (2016). Kajian Sistem Polinasi Daemonorops draco (willd.) Blume. Floribunda, 4(7).

BPS (2018). Kecamatan Peusangan Selatan dalam Angka 2018. https://bireuenkab.bps.go.id/publication/2018/09/26/ec ebf6ab3372927903fe8270/kecamatan-peusangan-selatandalam-angka-2018.html

Coppen, J. J. (1995). Gums, resins and latexes of plant origin. Nonwood forest products 6. Rome: Food and Agriculture Organization of the United Nations $x, 142 p$. ISBN, 661102982.

Gafar, P. A. (2010). Performa Teknologi Dan Mutu Jernang Produksi Indonesia. Journal of Industrial Research (Jurnal Riset Industri), 4(3), 37-44.

Gupta, D., Bleakley, B., \& Gupta, R. K. (2008). Dragon's blood: botany, chemistry and therapeutic uses. Journal of ethnopharmacology, 115(3), 361-380.

Januminro, C. (2000). Rotan Indonesia. Penerbit Kanisius. Yogyakarta.

Lestari, S. (2017). Dragon'blood as the Community Life Support: Case of Muara Enim Regency, South Sumatra Province. Jurnal Penelitian Sosial dan Ekonomi Kehutanan, 14(3), 191203.

Matangaran, J. R., \& Puspitasari, L. (2012). Potensi dan Pemanenan Buah Rotan Jernang. Jurnal Silvikultur Tropika, 3(1).

Purwanto, Y., Polosakan, R., Susiarti, S., \& Walujo, E. (2005). Ekstraktivisme Jernang (Daemonorops spp) dan Kemungkinan Pengembangannya. Laporan Teknik. Bidang Botani, Pusat Penelitian Biologi-LIPI. 
Ran, Y., Wang, R., Lin, F., Hasan, M., Jia, Q., Tang, B., ... Li, Q. (2014). Radioprotective effects of Dragon's blood and its extract against gamma irradiation in mouse bone marrow cells. Physica Medica, 30(4), 427-431.

Rao, G., Gerhart, M., Lee III, R., Mitscher, L., \& Drake, S. (1982). Antimicrobial agents from higher plants. Dragon's blood resin [Daemonorops draco]. Journal of natural products (USA).

Rustiami, H., Setyowati, F., \& Kartawinata, K. (2004). Taxonomy and uses of Daemonorops draco (Willd.) Blume. Journal of Tropical Ethnobiology, 1(2), 65-75.

Sahwalita. (2014). Budidaya Rotan Jernang. Balai Penelitian Kehutanan Palembang.

Sulasmi, I. S., Purwanto, Y., \& Fatimah, S. (2012). Rattan Jernang (Daemonorops draco) management by Anak Dalam Tribe in Jebak Batanghari, Jambi Province. Biodiversitas, 13(3), 152162.

Waluyo, T. K. (2008). Teknik ekstraksi tradisional dan analisis sifatsifat jernang asal Jambi. J Penelitian Hasi Hutan, 26(1), 3040.

Waluyo, T. K. (2013). Perbandingan Sifat Fisiko-kimia 5 Jenis Jernang. Jurnal Penelitian Hasil Hutan, 31(2), 141-150.

Waluyo, T. K., \& Pasaribu, G. (2015). Aktivitas Antijamur, Antibakteri dan Penyembuhan Luka Ekstrak Resin Jernang (Antifungal, Antibacterial and Wound Healing Activity of Dragon's blood Extracts).

Waluyo, T. K., \& Pasaribu, G. (2015). Aktivitas Antijamur, Antibakteri Dan Penyembuhan Luka Ekstrak Resin Jernang. Jurnal Penelitian Hasil Hutan, 33(4), 377-385. 
Winarni, I, Waluyo, TK, Hastuti, P (2005). Sekilas tentang Jernang sebagai Komoditi yang Layak dikembangkan. Prosiding Ekspose Hasil Hasil Litbang Hasil Hutan. Bogor: Pusat Penelitian dan Pengembangan Hasil Hutan. Hal 173 - 177.

Xia, M.-Y., Wang, M.-W., Cui, Z., Tashiro, S.-I., Onodera, S., Minami, M., \& Ikejima, T. (2006). Dracorhodin perchlorate induces apoptosis in HL-60 cells. Journal of Asian natural products research, 8(4), 335-343.

Yetty, Y., Hariyadi, B., \& Murni, P. (2013). Studi Etnobotani Jernang (Daemonorops spp.) pada Masyarakat Desa Lamban Sigatal dan Sepintun Kecamatan Pauh Kabupaten Sarolangun Jambi. Biospecies, 6(01). 